\title{
STRATEGI PENGEMBANGAN EKO-WISATA BERBASIS MASYARAKAT DI KAMPUNG WISATA REJOWINANGUN
}

\author{
Endah Tisnawati', Dita Ayu Rani Natalia', Desrina Ratriningsih ${ }^{1}$, Angling Randhiko Putro', \\ Wiliarto Wirasmoyo', Henry P. Brotoatmodjo², Adwiyah Asyifa'3 \\ ${ }^{1}$ Program Studi Arsitektur, Universitas Teknologi Yogyakarta; \\ 2Jurusan Teknik Informatika, Universitas Amikom; \\ ${ }^{3}$ Program Studi Teknik Sipil, Universitas Teknologi Yogyakarta \\ Email: endah.tisnawati@uty.ac.id
}

\begin{abstract}
Community-based ecotourism is one of the efforts of rural development through the tourism sector, which not only presents natural tourism resources, but also contributes to environmental conservation, and the community as the main controller in its development. Rejowinangun Tourism Village is a village with a lot of potential and began to be developed as an ecotourism area, but still has many problems, both from the environmental aspects, management aspects, to aspects of human resources, so that tourism activities in the region have not developed. Therefore, a study is needed to analyze the potentials of community-based ecotourism development in Rejowinangun Tourism Village, and to achieve these objectives, an analysis is conducted on all aspects, namely analysis on aspects of tourist objects and attractions, social aspects, management aspects, up to aspects of organizing community empowerment. In collecting data, the method used is community participatory. In this method the community is the central focus and the ultimate goal of the activity, citizen participation will increase citizens' self-esteem and the ability to be able to participate in the mission concerning the community and village. Citizen participation will foster an environment that is conducive to increasing environmental potential and community growth.
\end{abstract}

Keywords: Community-Based Ecotourism, Ecotourism, Rejowinangun Tourism Village

\begin{abstract}
ABSTRAK
Ekowisata berbasis masyarakat merupakan salah satu upaya pengembangan pedesaan melalui sektor pariwisata, yang tidak hanya menyuguhkan sumber daya wisata yang masih alami, namun juga berkontibusi terhadap konservasi lingkungan, dan masyarakat sebagai pengendali utama dalam pengembangannya. Kampung Wisata Rejowinangun merupakan kampung dengan banyak potensi dan mulai dikembangkan sebagai kawasan ekowisata, namun masih memiliki banyak permasalahan, baik dari aspek lingkungan, aspek pengelolaan, hingga aspek sumberdaya manusia, sehingga aktivitas wisata di kawasan tersebut belum berkembang. Oleh karena itu, diperlukan suatu kajian untuk menganalisis potensi-potensi pengembangan ekowisata berbasis masyarakat di Kampung Wisata Rejowinangun, dan untuk mencapai tujuan tersebut, dilakukan analisis pada semua aspek, yaitu analisis pada aspek objek dan daya tarik wisata, aspek kemasyarakatan, aspek pengelolaan, hingga aspek penyelenggaraan pemberdayaan masyarakat. Dalam pengumpulan data, metode yang digunakan adalah partisipatoris masyarakat. Di dalam metode ini masyarakat adalah fokus sentral dan tujuan terakhir kegiatan, partisipasi warga akan meningkatkan harga diri warga dan kemampuan untuk dapat turut serta dalam keutusan yang menyangkut masyarakat dan kampung. Partisipasi warga dapat menumbuhkan lingkungan yang kondusif bagi peningkatan potensi lingkungan dan pertumbuhan masyarakat.
\end{abstract}

Kata kunci: Ekowisata Berbasis Masyarakat, Ekowisata, Kampung Wisata Rejowinangun 


\section{PENDAHULUAN}

Kota Yogyakarta yang merupakan salah satu wilayah yang terletak di DIY mempunyai potensi wisata yang berkembang dengan pesat. Salah satu jenis daya tarik wisata yang dikembangkan saat ini adalah desa/kampung wisata. Desa wisata didefinisikan sebagai desa yang memiliki potensi keunikan dan daya tarik wisata yang khas, baik berupa karakter fisik lingkungan alam pedesaan maupun kehidupan sosial budaya kemasyarakatan yang dikelola dan dikemas secara menarik dan alami dengan pengembangan fasilitas pendukung wisatanya, dalam suatu tata lingkungan yang harmonis dan pengelolaan yang baik dan terencana sehingga siap menerima dan menggerakkan kunjungan wisatawan ke desa tersebut, serta mampu menggerakkan (Muliawan, 2000).

Prinsip pengembangan desa/kampung wisata adalah sebagai salah satu produk wisata alternatif yang dapat memberikan dorongan bagi pembangunan kawasan yang berkerlanjutan serta memiliki prinsipprinsip pengelolaan (Bappeda, 2013). Seiring dengan perkembangannya, muncul konsep ekowisata berbasis masyarakat, yaitu konsep wisata yang menyuguhkan sumber daya alam wilayah dan budaya setempat yang memiliki nilai konservasi serta mampu meningkatkan pendapatan ekonomi bagi masyarakat.
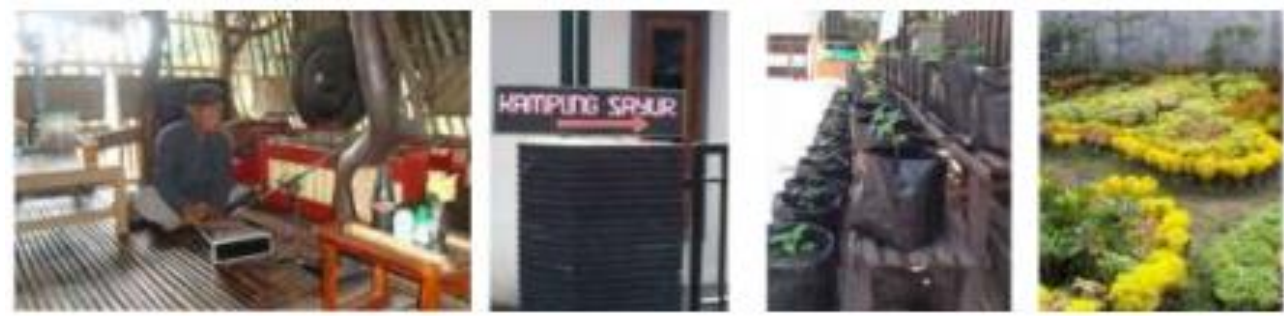

Gambar 1. Kegiatan Budaya dan Wisata Agro di Kampung Wisata Rejowinangun (Sumber: Monografi Kelurahan Rejowinangun, 2017)

Kampung wisata Rejowinangun terletak di Kelurahan Rejowinangun Kecamatan Kotagede. Kecamatan Kotagede merupakan salah satu obyek tujuan wisata bagi wisatawan dosmetik maupun mancanegara. Kotagede mempunyai obyek wisata minat khusus berupa makam Raja Mataram yang terletak di kelurahan Prenggan. Menurut data, tahun 2014 Kelurahan Rejowinangun paling banyak dikunjungi oleh wisatawan asing sebanyak 15.785 orang dan wisatawan domestik sebanyak 1.608 .643 orang (Dinas Kebudayaan dan Pariwisata Propinsi DIY, 2015). Dengan jumlah wisatawan yang banyak mendorong masyarakat untuk mengembangkan wisata lain sebagai obyek daya tarik wisata baru yaitu kampung wisata Rejowinangun yang memiliki ciri khusus. Saat ini dalam RPJMD Kota Yogyakarta tahun 2016-2026, Kelurahan Rejowinangun termasuk dalam Masterplan
Pengembangan Eco-district Kota Yogyakarta. Perencanaan ini membawa dampak pada arahan pengembangan konsep kepariwisataan kampungnya.

Pendekatan Eco-district memayungi pola pengembangan ekowisata. Pola ekowisata berbasis masyarakat adalah pola pengembangan ekowisata yang mendukung dan memungkinkan keterlibatan penuh oleh masyarakat setempat dalam perencanaan, pelaksanaan, dan pengelolaan usaha ekowisata dan segala keuntungan yang diperoleh (Departemen Kebudayaan dan Pariwisata dan WWF-Indonesia, 2009). Ekowisata berbasis masyarakat dapat menciptakan kesempatan kerja bagi masyarakat setempat, dan mengurangi kemiskinan, di mana penghasilan ekowisata adalah dari jasa-jasa wisata untuk turis: biaya pemandu; ongkos transportasi; homestay; menjual kerajinan, 
dll. Ekowisata membawa dampak positif terhadap pelestarian lingkungan dan budaya asli setempat yang pada akhirnya diharapkan akan mampu menumbuhkan jati diri dan rasa bangga antar penduduk setempat yang tumbuh akibat peningkatan kegiatan ekowisata.

Dengan adanya pola ekowisata berbasis masyarakat bukan berarti bahwa masyarakat akan menjalankan usaha ekowisata sendiri. Tataran implementasi ekowisata perlu dipandang sebagai bagian dari perencanaan pembangunan terpadu yang dilakukan di suatu daerah. Untuk itu, pelibatan para pihak terkait mulai dari level komunitas, masyarakat, pemerintah, dunia usaha dan organisasi non pemerintah diharapkan membangun suatu jaringan dan menjalankan suatu kemitraan yang baik sesuai peran dan keahlian masingmasing.

Dowling (1996), dalam Hill \& Gale (2009) menyatakan bahwa ekowisata dapat dilihat berdasarkan keterkaitannya dengan 5 (lima) elemen inti, yaitu bersifat alami, berkelanjutan secara ekologis, lingkungannya bersifat edukatif, menguntungkan masyarakat lokal, dan menciptakan kepuasan wisatawan. Berdasarkan definisi-definisi dari berbagai tokoh, Fennell (2003) kemudian merangkum pengertian eko-wisata sebagai sebuah bentuk berkelanjutan dari wisata berbasis sumberdaya alam yang fokus utamanya adalah pada pengalaman dan pembelajaran mengenai alam, yang dikelola dengan meminimalisir dampak, non-konsumtif, dan berorientasi lokal (kontrol, keuntungan dan skala). Goeldner (1999), dalam Butcher (2007), menyatakan bahwa ekowisata merupakan bentuk perjalanan menuju kawasan yang masih alami yang bertujuan untuk memahami budaya dan sejarah alami dari lingkungannya, menjaga integritas ekosistem, sambil menciptakan kesempatan ekonomi untuk membuat sumber daya konservasi dan alam tersebut menguntungkan bagi masyarakat lokal. Terlihat jelas bahwa perlu adanya keuntungan yang didapatkan oleh masyarakat lokal, sehingga ekowisata harus dapat menjadi alat yang potensial untuk memperbaiki peri-laku sosial masyarakat untuk tujuan konser-vasi lingkungan (Buckley, 2003).

Adimihardja (1999) dalam Sunaryo (2013) mendefinisikan pemberdayaan masyarakat sebagai suatu proses yang tidak saja hanya mengembangkan potensi ekonomi masyarakat yang sedang tidak berdaya, namun demikian juga harus berupaya dapat meningkatkan harkat dan martabat, rasa percaya diri dan harga dirinya serta terpeliharanya tatanan nilai budaya setempat. Pemberdayaan masyarakat dimaknai sebagai suatu upaya untuk menguatkan power (daya) atau empowering dari golongan masyarakat yang powerless (tidak berdaya), biasanya mereka yang sedang tergolong ke dalam masyarakat yang marjinal. Sinclair (1998) dalam Okazaki (2008) menyebutkan bahwa pariwisata mampu memberikan manfaat dalam bentuk penguatan ekonomi lokal, yang antara lain berupa devisa, pendapatan tambahan kepada masyarakat, serta peluang pekerjaan yang dapat ditangkap oleh masyarakat. Ramadhan (2018) berpendapat, sektor usaha dalam pariwisata seperti usaha akomodasi dan transportasi dapat memberikan kontribusi dalam mendorong perekonomian lokal, regional, maupun nasional. Dalam kegiatan kepariwisataan ada beberapa pihak yang memiliki peran dan terlibat langsung dalam kegiatan kepariwisataan (Sunaryo, 2013).

Murphy (1988), Larry Dawyer, Peter Forsyth dan Wayne Dwyer (2010) dalam Sunaryo (2013) pembangunan kepariwisataan harus merupakan suatu kegiatan yang berbasis pada komunitas, dengan faktor utama bahwa sumber daya dan keunikan komunitas lokal baik berupa elemen fisik maupun non fisik (tradisi dan budaya) yang melekat pada komunitas tersebut harus menjadi penggerak utama dalam pariwisata tersebut. Masyarakat lokal memiliki kedudukan yang sama pentingnya sebagai salah satu pemangku kepentingan (stakeholder) dalam pembangunan kepariwisataan, selain pihak pemerintah dan industri swasta. 
Berdasarkan konsep pemberdayaan masyarakat dalam pembangunan kepariwisataan, Phillips (2009), Okazaki (2008) dan Chuang (2010) menyampaikan bahwa upaya pemberdayaan masyarakat melalui kepariwisataan pada hakikatnya harus diarahkan pada beberapa hal sebagai bertikut:

1. Meningkatnya kapasitas, peran dan

\section{METODE}

Metode yang digunakan dalam Pengembangan Ekowisata di Kampung Wisata Rejowinangun ini mengedepankan kepentingan masyarakat dalam membangun lingkungannya agar lebih tertata dan memiliki karakter budaya yang kuat. Pendekatan yang dilakukan di tahun pertama adalah pendekatan perancangan partisipatoris masyarakat. $\mathrm{Di}$ dalam metode ini masyarakat adalah fokus sentral dan tujuan terakhir kegiatan, partisipasi warga akan meningkatkan harga diri warga dan kemampuan untuk dapat turut serta dalam keutusan yang menyangkut masyarakat dan kampung. Partisipasi warga akan menumbuhkan lingkungan yang kondusif bagi peningkatan potensi lingkungan dan pertumbuhan masyarakat.

Muslim (2007) dan Okazaki (2008) menjelaskan bahwa masyarakat harus terlibat aktif dalam setiap pengambilan keputusan bersama dengan pemerintah daerah. Partisipasi dari masyarakat dibutuhkan dalam bentuk:

1. Keterlibatan dalam kegiatan pendataan dan identifikasi kawasan (potensi dan masalah)

2. Keterlibatan dalam proses perencanaan kawasan yang nantinya akan meng-

\section{HASIL DAN PEMBAHASAN}

\section{Kampung Wisata Rejowinangun}

Kampung wisata Rejowinangun dirintis sejak tahun 2010 dan diresmikan pada tahun 2013. Kampung wisata ini meliputi di seluruh Kelurahan Rejowinangun dengan adanya pembagian klaster yang
Strategi Pengembangan ... (Endah/ hal 1-11)

inisiatif masyarakat pembangunan kepariwisataan.

2. Meningkatnya posisi dan kualitas keterlibatan/partisipasi masyarakat.

3. Meningkatnya nilai manfaat positif pembangunan kepariwisataan bagi kesejahteraan ekonomi masyarakat.

4. Meningkatnya kemampuan masyarakat dalam melakukan perjalanan wisata

hasilkan keluaran berupa visi misi kampung budaya, konsep tata lingkungan dan dokumen perencanaan.

3. Keterlibatan dalam pelaksanaan kegiatan, baik pelaksanaan sosialisasi, workshop maupun kegiatan fisik.

4. Monitoring dan Evaluasi, masyarakat dilibatkan untuk menilai hasil yang telah dilaksanaknan.

5. Keterlibatan dalam kegiatan perkuatan kelembagaan dan sosial budaya masyarakat untuk mewujudkan Kelurahan Rejowinangun sebagai Kampung Wisata.

Kerangka pendekatan pengembangan desa wisata sangat dipengaruhi oleh kebijakan dan parameter pendampingan yang ditetapkan oleh pemerintah, di mana pendekatan ini dimaksudkan untuk dapat menghasilkan suatu perangkat peraturan tata lingkungan yang selain menciptakan keteraturan juga dapat mendukung terciptanya faktor estetika kawasan yang menonjolkan ciri khas daerah tersebut dalam bentuk tata letak, desain bangunan, kekhasan seni budaya serta sarana pendukung lingkungan kawasan. bertujuan agar potensi wilayah dapat berkembang dengan baik dan masyarakat dapat maju bersama. Pembagian klaster didasarkan pada batas RW. Setiap klaster mewakili potensi utama kawasan, yaitu 
klaster budaya, klaster agro, klaster herbal, klaster kuliner dan Kampung wisata Rejowinangun dapat dikembangkan menjadi memiliki potensi wisata alam dan budaya ekowisata berbasis masyarakat karena

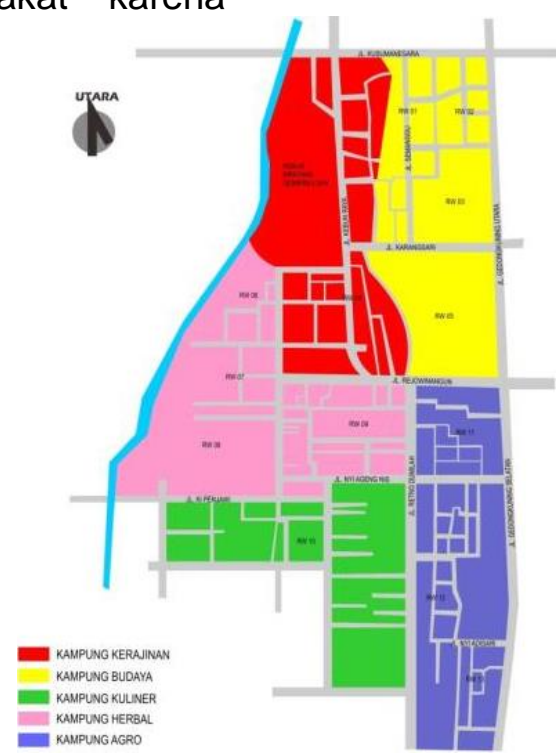

Gambar 2. Peta pembagian Klaster di Kelurahan Rejowinangun (Sumber: BPS Kota Yogyakarta, 2015)

Beragamnya potensi yang dimiliki setiap klaster harus disimpulkan menjadi konsep kawasan Kampung Wisata Rejowinangun. Penataan yang menitikberatkan pada ekonomi dan lingkungan yang berkelanjutan termasuk peningkatan kapasitas sumber daya manusia untuk mencapai kesejahteraan masyarakat. Berikut uraian potensi setiap klasternya:

1. Klaster Budaya. Klaster ini terletak di sisi utara Kampung Wisata Rejowinangun. Memiliki beberapa potensi seni dan budaya sehingga ditetapkan menjadi klaster budaya. Pada klaster ini terdapat 3 (tiga) potensi utama, yaitu Sanggar Tari Sari Budoyo dengan tarian Edan-edanan, Sanggar Tari Sekar Arum dan kelompok Karawitan dan Panembromo Retno Budoyo Rini.

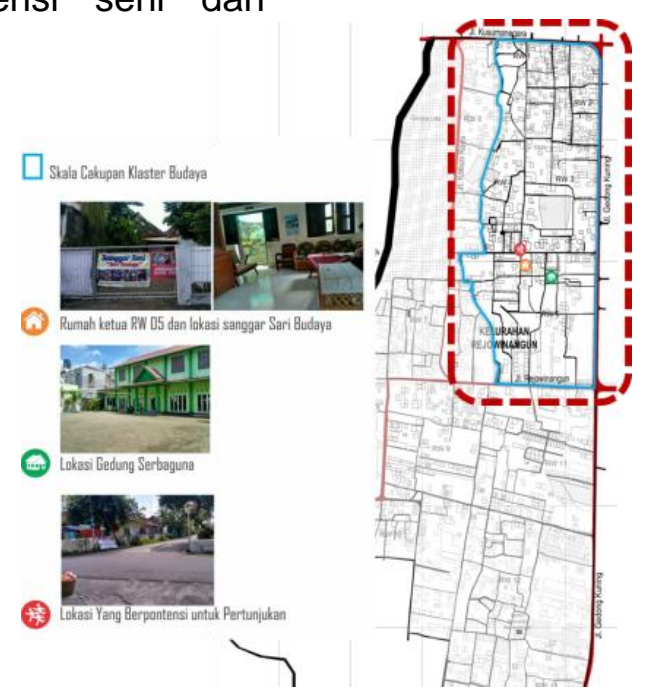

Gambar 3. Peta Potensi Budaya Klaster Rejowiangun 
Sanggar Tari Sekar Arum merupakan sanggar tari tradisional khususnya tari jawa. Rutin berlatih setiap hari Kamis sore pukul 16.00 wib di pendopo Bapak Frans Gunawan yang berada di Rejowinangun
RW 09. Karawitan dan Penmbrono Retno Budoyo Rini berlokasi di Jalan Ki Penjawi no 37 dan di bawah pembinaan bapak Untung Suparjo yang rutin berlatih setiap hari Jumat.

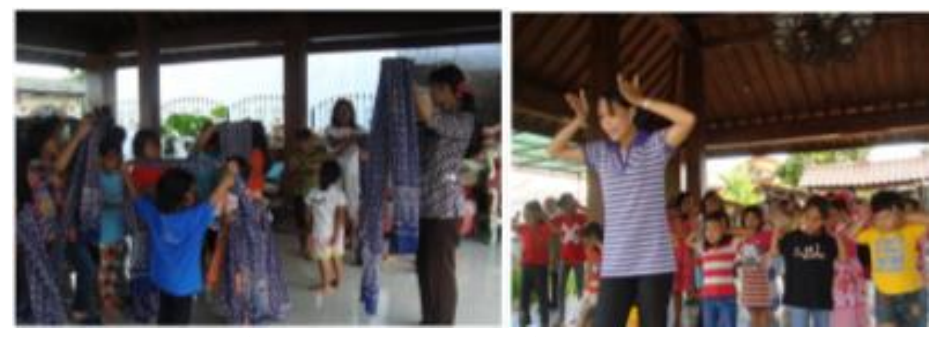

Gambar 4. Kegiatan Sanggar Tari

Adapun kegiatan kebudayaan di beberapa RW lainnya seperti:

RW 1 : keroncong dan karawitan

RW 2 : manuk beri, yang berupa peninggalan jaman dahulu

RW 3 : gamelan, terdapat peralatan gamelan tapi belum efektif penggunaannya

RW 5 : seni tari, macapat, ketoprak, jatilan

Dari seluruh kelompok di klaster budaya RW 5 adalah yang paling aktif dalam kegiatan kebudayaan. Tari edan-edanan adalah tarian yag paling terkenal juga sebagai ciri khas Kampung Rejowinangun.

2. Klaster Kerajinan. Klaster ini terletak di sisi barat Kampung Wisata Rejowinangun. Klaster kerajinan terletak di RW 6 dan RW 7, disini banyak sekali pengrajin atau warga yang mempunyai usaha kerajinan. Beberapa potensi kerajinan yang tersebar dalam klaster ini yaitu: kerajinan batik, kerajinan lukis kaca terbalik, kerajinan fiber, kerajinan blangkon, kerajinan dari sampah an organik dan sanggar rajut.

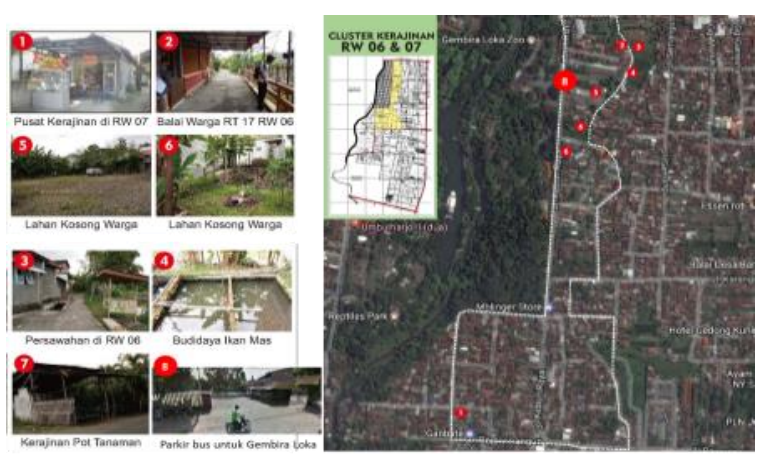

Gambar 5. Peta Potensi Klaster Kerajinan
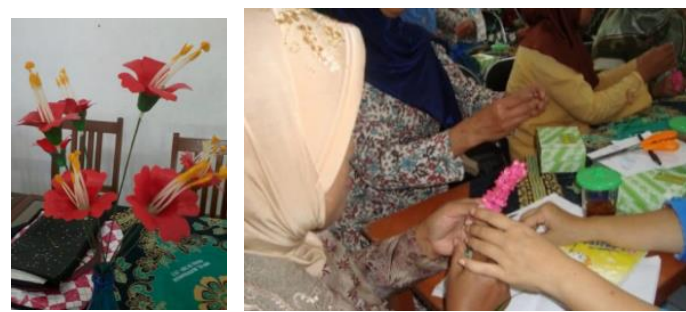

Gambar 6. Hasil Klaster Kerajinan 
3. Klaster Herbal. Terletak di sisi barat Kampung Wisata Rejowinangun. Produk unggulan klaster ini adalah JAGER (jamu gendong Rejowinangun) yang memproduksi aneka jamu tradisional secara alami. Produk jamu ini juga sudah menjadi produk unggulan beberapa hotel berbintang di Yogyakarta.

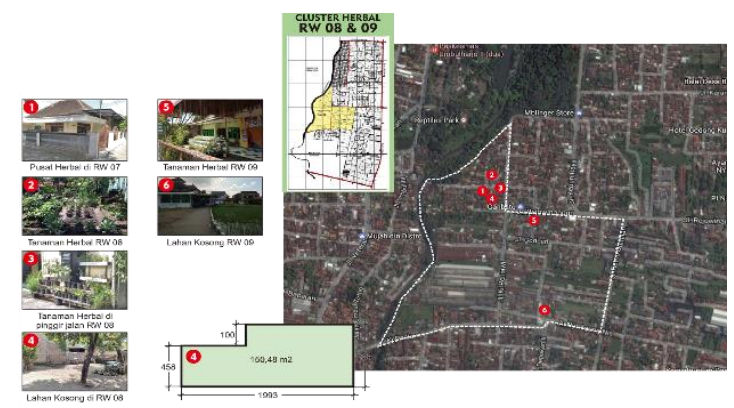

Gambar 7. Peta Potensi Klaster Herbal

4. Klaster Kuliner. Terletak di sisi selatan Kampung Wisata Rejowinangun. Produk unggulan klaster ini adalah berbagai variasi kripik daun yang sudah bersertifikasi dari BPOM. Ibu ibu penggerak klaster kuliner juga telah secara rutin menggelar pasar jajanan untuk berbuka puasa setiap bulan puasa.

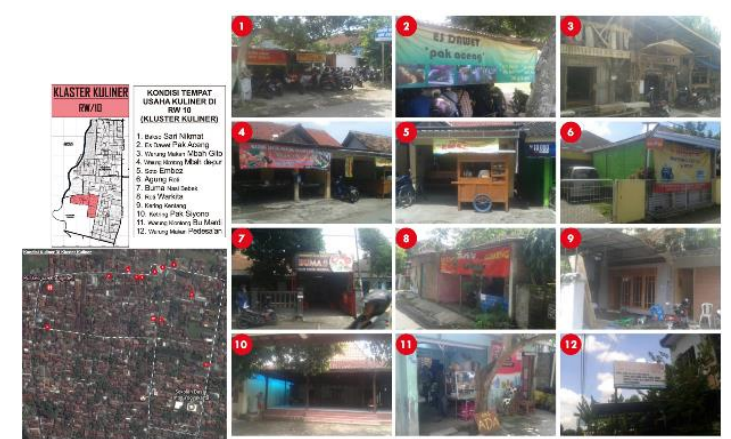

Gambar 8. Peta Potensi Klaster Kuliner

5. Klaster Agro. Terletak di sisi timur Kampung Wisata Rejowinangun. Setiap rumah di klaster agro menanam sayuran di dalam pot. Setiap tahunnya digelar event Merti Panen Raya. Klaster ini telah dibina oleh Dinas Pertanian dan Ketahanan Pangan.

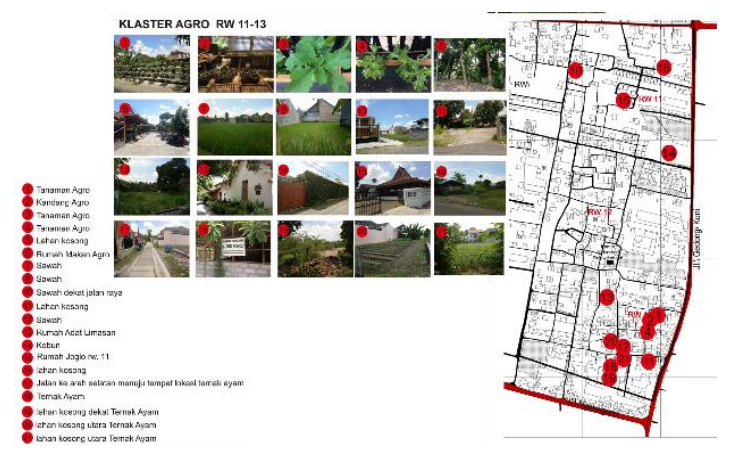

Gambar 9. Peta Potensi Klaster Agro 


\section{Analisis Pengembangan Potensi Ekowisata di Kampung Wisata Rejowinangun}

Dowling (1996) dalam Hill \& Gale (2009) dan Fennell (2003), berpendapat prinsip utama dalam pengembangan konsep Eko-wisata adalah terdapatnya lingkungan yang alami dan ekologis. Kampung Wisata Rejowinangun terletak di Kota Yogyakarta dengan karakter kampung perkotaan. Hal ini tentu saja menjadikan tantangan tersendiri dalam pengembangan konsep ekowisata yang berbasis pada pengembangan konservasi alam dan lingkungan. Klaster agro dan klaster herbal yang terdapat dalam kawasan menjadi tulang punggung pengembangan konsep ini dalam kawasan. Selain itu dalam kawasan kelurahan juga terdapat Sungai Gajahwong dengan kondisi lingkungan yang masih alami.

Klaster Agro mulai tahun 2018 ini mendapat kesempatan dampingan dari Dinas Pertanian dan Ketahanan Pangan untuk mengembangkan konsep Agrowisata. Agrowisata perkotaan merupakan salah satu konsep kegiatan pariwisata yang bertemakan pertanian dan akhir-akhir ini menjadi alternatif tujuan wisata bagi keluarga di kawasan perkotaan. Selain itu, pergeseran dan perubahan gaya hidup masyarakat perkotaan turut memicu perkembangan agrowisata yang diperkuat dengan isu terbatasnya lahan hijau/lahan tanam. Beberapa manfaat dari konsep agrowisata perkotaan ini antara lain: sebagai wahana untuk mendiseminasikan berbagai teknologi pertanian kepada masyarakat secara umum; sebagai kegiatan dalam rangka memanfaatkan dan melestarikan ling-kungan sekitar; meningkatkan pendapatan petani perkotaan dan membuka lapangan pekerjaan bagi masyarakat sekitar; serta menambah nilai estetika pada lingkungan sekitar.

Pada Klaster Agro, konsep agrowisata perkotaan ini dirancang dengan memanfaatkan lahan yang terbatas, misalnya dengan vertikultur, hidroponik, pergola, media tanam vertikal, serta inovasi lainnya yang dapat diterapkan dalam pertanian perkotaan. Pengembangan agrowisata perkotaan di kawasan ini merupakan salah satu bentuk pemberdayaan masyarakat yang membutuhkan dukungan dari kelembagaan lokal, lembaga keuangan dan pihak terkait, serta menggerakkan beberapa aspek dalam mayarakat yaitu aspek ekonomi, aspek sosial budaya dan aspek lingkungan. Menumbuh-kembangkan agrowisata perkotaan yang berbasis pemberdayaan masyarakat sekitar tidaklah mudah, titik-titik kritis yang menentukan keberhasilan antara lain permodalan, kemampuan pengelola, motivasi dan passion serta kebersamaan dan kesolidan masyarakat dan pengelola.

Maksud pelaksanaan kegiatan ini selain untuk mengembalikan nilai-nilai tradisional yang ada, juga memberi makna untuk selalu mensyukuri kehidupan dan tetap menjaga lingkungan. Selain itu, penyelenggaraan kegiatan ini juga dimaksudkan untuk memberikan motivasi kepada petani perkotaan agar terus memelihara lahan tanam sebagai bentuk ketahanan pangan. Kegiatan Merti Panen Raya ini merupakan kegiatan rutin dan menjadi salah satu atraksi wisata yang memperkuat potensi Klaster Agro Kampung Wisata Rejowinangun.

Dukungan utama tentu saja dari masyarakat Kelurahan Rejowinangun yang telah berkomitmen untuk memberdayakan wilayahnya di bidang pertanian dan diseminasi tanaman. Kegiatan ini bermula dari sekedar hobby, dan keinginan untuk menjaga lingkungan agar tetap hijau, kemudian berkembang menjadi komitmen untuk membentuk kelompok tani dan kelompok wanita tani.

Dukungan dari Pemkot diberikan melalui Dinas Pertanian dan Ketahanan Pangan Kota Yogyakarta yang telah memberikan bantuan, baik berupa bibit, infrastruktur pertanian maupun kegiatan pelatihan serta rumusan rancangan grand desain. Berbagai kegiatan pendampingan dan perkuatan UMKM telah dikucurkan melalui Kecamatan Kotagede dengan tujuan memperkuat system klaster yang telah berkembang dengan baik di Kelurahan Rejowinangun. 
Dukungan pemerintah lainnya adalah hadirnya Wakil Walikota Yogyakarta dalam kegiatan ini.

Kemitraan juga dirintis bersama perguruan tinggi. Program Studi Arsitektur, Universitas Teknologi Yogyakarta, sejak tahun 2016 lalu telah melakukan kegiatan pendampingan masyarakat Perencanaan Kampung Wisata Rejowinangun. Kegiatan ini mendapat pendanaan dari Kementrian Riset, Teknologi dan pendidikan Tinggi, dan saat ini telah memasuki tahun kedua. Program yang telah berjalan hingga saat ini adalah Perumusan Masterplan Kampung Wisata, Perumusan dan Perencanaan Klaster Agro Wisata, Pengadaan Papan informasi wisata, pengadaan desain area swa foto, pendampingan perkuatan kelembagaan, dukungan bantuan kepada UMKM untuk memperkuat sarana prasarana pendukung potensi wisata di Kelurahan Rejowinangun.
Tahun 2018 Kampung Wisata Rejowinangun telah mendapatkan akreditasi kampung wisata yang diselenggarakan oleh Dinas Pariwisata Kota Yogyakarta. Prestasi Kampung Wisata Rejowinangun pun tidak sedikit. Tahun 2018 ini menjadi kampung wisata kedua terbaik se-Propinsi DIY. Mendapat juara kedua pada Festival Kampung Wisata Kota Yogyakarta. Di tingkat nasional, Kampung Wisata Rejowinangun memperoleh peringat ke-18. Kondisi ini tidak lepas dari arah perkembangan konsep ekowisata yang dikembangkan di wilayah tersebut.

Analisis potensi yang ada di Kampung Wisata Rejowinangun dalam kerangka mengembangkan konsep Ekowisata dapat dilihat pada table di bawah ini.

Tabel 1. Analisis Potensi Pengembangan Ekowisata Kampung Wisata Rejowinangun

\begin{tabular}{|c|c|c|}
\hline $\begin{array}{l}\text { Parameter } \\
\text { Ekowisata }\end{array}$ & Kondisi di Kampung Wisata Rejowinangun & Keterangan \\
\hline Bersifat alami & $\begin{array}{l}\text { Pengembangan konsep pertanian lahan sempit dan } \\
\text { Agrowisata }\end{array}$ & $\begin{array}{l}\text { Terdapat } \\
\text { kualitas }\end{array}$ \\
\hline $\begin{array}{l}\text { Berkelanjutan secara } \\
\text { ekologis }\end{array}$ & Adanya berbagai pelatihan peningkatan kualitas lingkungan & $\begin{array}{lr}\text { Peningkatan } & \text { kualitas } \\
\text { dan } & \text { diversifikas } \\
\text { kegiatan }\end{array}$ \\
\hline $\begin{array}{l}\text { Lingkungannya } \\
\text { bersifat edukatif }\end{array}$ & $\begin{array}{l}\text { Rumusan paket wisata bersifat pendidikan untuk siswa dan } \\
\text { umum }\end{array}$ & $\begin{array}{l}\text { Baru bersifat embrio } \\
\text { dan siap dilaksanakan }\end{array}$ \\
\hline $\begin{array}{l}\text { Menguntungkan } \\
\text { masyarakat lokal }\end{array}$ & $\begin{array}{l}\text { Peningkatan usaha ekonomi masyarakat dalam upaya } \\
\text { mendukung potensi wisata, seperti souvenir shop (baik kuliner } \\
\text { maupun kerajinan), warung makan, dll }\end{array}$ & $\begin{array}{l}\text { Peningkatan } \begin{array}{l}\text { kualitas } \\
\text { dan } \\
\text { kegiatan }\end{array} \\
\end{array}$ \\
\hline $\begin{array}{l}\text { Menciptakan } \\
\text { kepuasan wisatawan }\end{array}$ & $\begin{array}{l}\text { Penetapan konsep Agrowisata pada klaster Agro. } \\
\text { Akreditasi Kampung Wisata. } \\
\text { Penghargaan Kampung Wisata tingkat Nasional }\end{array}$ & $\begin{array}{l}\text { Peningkatan } \begin{array}{l}\text { kualitas } \\
\text { dan diversifikas } \\
\text { kegiatan }\end{array} \\
\end{array}$ \\
\hline
\end{tabular}

Sumber: Dowling (1996) dalam Hill \& Gale (2009) dan analisa penulis (2018)

\section{Analisis Penerapan Pengembangan Wisata berbasis Masyarakat di Kampung Wisata Rejowinangun}

Sunaryo (2013) menyatakan bahwa untuk mewujudkan pengembangan pariwisata berjalan dengan baik dan dikelola dengan baik maka hal yang paling mendasar dilakukan adalah bagaimana memfasilitasi keterlibatan yang luas dari komunitas lokal dalam proses pengembangan dan memaksimalkan nilai manfaat sosial dan ekonomi dari kegiatan pariwisata untuk masyarakat setempat. Kondisi ini dapat tercapai dengan melihat aspek kemasyarakatan dan aspek penyelenggaraan pemberdayaan masyarakat (Okazaki, 2008).

Menurut Okazaki (2008), analisis pada aspek kemasyarakatan dilakukan pada 4 (empat) variabel, yaitu karakter masyarakat, bentuk partisipasi masyarakat, peluang usaha, serta kualitas wisata dan kesiapan masyarakat. Berdasarkan perilaku atau gaya hidup, karakter masyarakat bersifat 
heterogen. Masyarakat di beberapa RW cukup antusias terhadap kegiatan wisata dan kegiatan lain yang berkaitan dengan pengembangan kampungnya, dan cukup peduli terhadap lingkungannya. Tetapi masyarakat di beberapa RW lainnya cenderung malas, pesimis, dan tidak peduli terhadap pengembangan potensi wisata di Kampung Rejowinangun. Karakter masyarakat yang cukup homogen adalah kecenderungannya untuk membuang sampah ke sungai. Kepedulian masyarakat terhadap lingkungan masih kurang, ditambah dengan kurangnya prasarana persampahan di hampir seluruh kampung. Belum ada masyarakat yang mempelopori terbentuknya bank sampah atau pemungutan sampah secara swadaya, sehingga mengurangi jumlah sampah yang dibuang ke sungai ataupun dibakar.

Adat istiadat di wilayah studi masih terjaga dengan baik, yang terbukti dengan masih lestarinya merti kampung serta masih lestarinya beberapa tradisi seperti kesenian daerah, gotong royong, nyadran, pengajian, merti dusun, syukuran, wayang.

Sebagian besar kegiatan wisata yang telah berjalan di Kawasan Rejowinangun kurang melibatkan masyarakat, sehingga masya-

\section{SIMPULAN}

Berdasarkan hasil analisis, dirumuskan konsep Kampung Wisata Rejowinangun berkonsep Eco District. Strategi Implementasi konsep ini berdasar pada Green Planning and Design, Green Openspace, Green Waste, Green transportation, Green Water, Green Energy, Green Building, dan Green Community. Di dalam konsep perancangan kawasan, Kampung Wisata Rejowinangun harus dapat menyatukan keragaman kelima klaster menjadi satu konsep besar penataan kawasan. Salah satu klaster ditetapkan menjadi sentra klaster. Elemen yang menyatukan klaster diantaranya yaitu: Gerbang Kampung Rejowinangun, Sentra rakat kurang merasakan manfaatnya. Hanya sedikit kegiatan wisata yang memiliki sistem pendistribusian keuntungan terhadap wilayahnya. Pengelolaan kegiatan wisata akan sangat baik jika melibatkan masyarakat di sekitar daerah wisata tersebut. Dengan memberdayakan masyarakat sekitar, keuntungan yang diperoleh tidak hanya dirasakan oleh pengelola kegiatan wisata, namun juga masyarakat di sekitarnya, sehingga dapat membantu meningkatkan ekonomi wilayah kampung di lokasi wisata tersebut.

Aspek penyelenggaraan pemberdayaan masyarakat dalam kajian ini dinilai dengan 3 (tiga) indikator, yaitu badan, peran, dan bentuk. Beberapa kelurahan telah memiliki kelompok sadar wisata (Pokdarwis) yang berperan dalam usaha memajukan kegiatan wisata yang sudah ada di beberapa desa serta mengembangkan potensi wisatanya. Bentuk kegiatan yang dilakukan adalah pelibatan masyarakat dalam pengelolaan kegiatan wisata, mencetuskan gagasan pelatihan pemandu wisata, mengembangkan promosi wisata, membuka lapangan pekerjaan dengan melibatkan masyarakat dalam kegiatan wisata, menampung gagasan pengembangan wisata, dan sebagainya

Cluster, Sclupture atau Penanda Cluster dan Penebalan Aksesibilitas.

Gerbang Kampung Rejowinangun ditempatkan di pusat kampung. Menjadi pintu utama Kampung Wisata Rejowinangun. Sementara, penanda kawasan ditempatkan di setiap klaster Kampung Wisata Rejowinangun. Sebagai petunjuk arah menuju klaster-klaster sekaligus menjadi identitas setiap klaster di Rejowinangun. Untuk konsep aksesibilitas Kampung Wisata Rejowinangun, ditempatkan shelter-shelter sepeda di beberapa titik untuk memudahkan mobilitas di dalam Kampung Wisata Rejowinangun. Perkuatan jalur jalan juga disertai perkuatan 
karakter kawasan dengan menambahkan desain elemen di sepanjang jalur jalan, seperti lampu jalan, perkerasan dan material jalan, dan lain-lain. Sentra klaster menjadi

\section{DAFTAR RUJUKAN}

Badan Perencanaan dan Pembangunan Daerah Kota Yogyakarta. (2013). Laporan akhir Studi Pengembangan Kampung Wisata Kota Yogyakarta.

Badan Pusat Statistik Kota Yogyakarta. (2015). Buku Kecamatan Kotagede dalam Angka tahun 2015. Penerbit BPS Kota Yogyakarta.

Buckley, Ralf. (2003). Case Studies in Ecotourism. Cambridge: CABI.

Butcher, Jim. (2007). Ecotourism, NGO's, and Development: A Critical Analysis. New York: Routledge.

Chuang, Shu-Tzu. (2010). "Rural Tourism: Perspective from Social Exchange Theory". Social Behavior and Personality Journal. Volume 38, Nomor 10, Halaman 1313. Taiwan: Society for Personality Research (Inc.).

Departemen Kebudayaan dan Pariwisata dan WWF-Indonesia. (2009). Prinsip dan Kriteria Ekowisata Berbasis Masyarakat,

Dinas Kebudayaan dan Pariwisata Propinsi DIY. (2015). Buku Statisitik Pariwisata Daerah Istimewa Yogyakarta tahun 2015. Penerbit Dinas Kebudayaan dan Pariwisata Propinsi DIY.

Fennell, David A. (2003). Ecotourism: An Introduction. Second Edition. New York: Routledge.

Hill, Jennifer dan Gale, Tim (Eds.). (2009). Ecotourism and Environmental pusat kegiatan dan awal tujuan wisatawan berkunjung sebelum diarahkan menuju ke setiap klaster. Merupakan etalase untuk memamerkan hasil dari setiap klaster.

Sustainability: Principles and Practice. Burlington: Ashgate.

Muliawan, H. (2000). Perencanaan dan Pengembangan Desa Wisata, Makalah disampaikandalam Diklat bidang Pariwisata bagi Kepala Desa di Propinsi DIY, tg 14-16 Agustus 2000, di Hotel Phoenix, Yogyakarta

Muslim, Aziz. (2007). Pendekatan Partisipatif Dalam pemberdayaan Masyarakat; Aplikasia, Jurnal Aplikasi ilmu-ilmu Agama, Vol. VIII hal 89-103

Okazaki, Etsuko. (2008). A CommunityBased Tourism Model: Its Conception and Use. Journal of Sustainable Tourism. Vol 16, No. 5. Taylor \& Francis, New York.

Phillips, Rhonda dan Pittman, Robert $\mathrm{H}$. (Eds.). (2009). An Introduction to Community Development. New York: Routledge.

Ramadhan, M. A., Pratama, G. N. I. P., \& Hidayah, R. (2018). Penataan Sistem Jalur Pejalan Kaki di Universitas Negeri Yogyakarta. INformasi dan Ekspose hasil Riset Teknik Slpil dan Arsitektur, 14(1), 101-117.

Sunaryo, Bambang. (2013). Kebijakan Pembangunan Destinasi Pariwisata Konsep dan Aplikasinya di Indonesia. Yogyakarta: Gava Media. 